\title{
ETS Domain-Containing Protein Elk-3
}

National Cancer Institute

\section{Source}

National Cancer Institute. ETS Domain-Containing Protein Elk-3. NCI Thesaurus. Code C17905.

ETS domain-containing protein Elk-3 (407 aa, $44 \mathrm{kDa}$ ) is encoded by the human ELK3 gene. This protein plays a role in signal transduction and gene transcription. 